\title{
Anaerobic Co-Digestion of Cattle Manure and Raw Algae: Kinetic Study and Optimization of Methane Potential by RSM
}

\author{
Arwa Abdelhay ${ }^{*}$, Lilian Al-Hasanat ${ }^{2}$, Abeer Albsoul ${ }^{3}$ \\ ${ }^{1}$ Civil and Environmental Engineering Department, German Jordanian University, Amman 11180 Jordan \\ ${ }^{2}$ Engineer, Environmental and Renewable Energy Engineering, German Jordanian University, Amman 11180 Jordan \\ ${ }^{3}$ Department of Chemical Engineering, Al-Huson University College, Al-Balqa Applied University, Irbid, Jordan
}

Received: 10 May 2020

Accepted: 18 July2020

\begin{abstract}
This paper investigated anaerobic co-digestion of cattle manure and raw algae with and without adding activated sludge as co- substrate and under different substrate ratios. The results showed that the co-digestion of cattle manure with raw algae led to a maximum methane yield of $294 \mathrm{~mL} / \mathrm{g}$ VS at a CM:A ratio of $70 \%: 30 \%$. While co-digestion of cattle manure and raw algae diluted with tap water under CM:A ratio of (70\%:30\%) resulted in a methane yield of $97 \mathrm{~mL} / \mathrm{g}$ VS. In the co-digestion runs conducted with the same feedstock and inoculated with activated sludge, little methane was produced. The values of $\mathrm{pH}$ and $\left(\mathrm{N}-\mathrm{NH}_{3}\right)$ showed no inhibitory effect. The kinetic study revealed that the maximum methane yield was 32.4 (mL/g VS.d), 332 ( $\mathrm{mL}$ methane/g VS) respectively. The lag time ranged from 0 to 3 days. The Response surface methodology showed that methane production could be represented by a second-order polynomial.
\end{abstract}

Keywords: anaerobic digestion $\mathrm{AD}$, cattle manure $\mathrm{CM}$, algae A, methane production, Response Surface Methodology RSM

\section{Introduction}

Energy shortfall and municipal solid waste (MSW) management are two key challenges that human kind is facing in the time being. Therefore, an integrated approach is essential to deal with the high pressure on fossil fuel as a primary source of energy and to mitigate the problem of waste disposal. Renewable energy recovery from organic biomass has gained recently much attention as it offers a sustainable combined

*e-mail: arwa.abdelhay@gju.edu.jo solution for both the high demand on fossil fuels and for the urgent need to the best practices in waste management [1]. Various processes and setups were proposed in literature to convert biomass into energy. Anaerobic digestion (AD) has been currently promoted as a way to stabilize and process the several types of biomass and waste residues for the production of biogas as an alternative of conventional energy sources [2-3]. However, the performance of $\mathrm{AD}$ in terms of energy revenues varies significantly based on the feedstock used. It has been reported that some organic substrates do not produce large biogas volumes when they are digested solely which makes the AD economically 
unfavorable [4]. The main reason of the weak biogas productivity in the case of mono-digestion has been attributed to the substrate low biodegradability or the imbalanced nutrients $(\mathrm{C} / \mathrm{N}$ ratio) or the accumulation of inhibitors/toxic compounds [5]. To improve the biogas potential, different AD modified systems have been explored. Namely, co-digestion, which consists of combining various substrates to be, digested simultaneously [6-7]. The selection of co-substrates in co-digestion should be made carefully to obtain a synergetic effect by balancing the nutrients or by minimizing the risk of inhibition that can be achieved by mixing appropriate ratios of substrates [8].

Nowadays, animal manure is among the solid waste that needs special attention. The increase in livestock production worldwide led to an accumulation of solid animal manure and the use of manure for land applications was not a solution as it resulted in soil and water pollution [9]. Thus, the concern for management of livestock wastes coupled with the demand for clean energy has revived an interest in generating methane from livestock manures. AD is considered as a potential way to stabilize animal manure prior to its use as soil amendment and to produce energy concurrently. However, due to inherent carbon deficiency in animal manure (low $\mathrm{C} / \mathrm{N}$ ratio), a second substrate is recommended to increase the $\mathrm{AD}$ performance and the energy revenues in the form of biogas. Many studies indicated that a proper $\mathrm{C} / \mathrm{N}$ ratio for anaerobic digestion is between 20-35 [10]. From a nutrient balance standpoint, although algal biomass can be converted to energy it does not seem a compatible co-substrate as it is also characterized by a low $\mathrm{C} / \mathrm{N}$ ratio $(<10)$ [11]. Nonetheless, limited researches reported the stabilization of animal manure and the enhancement of biogas potential using raw algae as a co-substrate [12-13]. Ramos-Suárez and Carreras (2014) [14] observed that improving AD performance is not always linked to the $\mathrm{C} / \mathrm{N}$ ratio of the mixture when using algae as co-substrate. In other words, the balance of the low $\mathrm{C} / \mathrm{N}$ ratio of algae by a carbon rich substrate would not always lead to a positive synergetic effect. [15] mentioned that animal manure and algae co digestion is feasible when adding a carbon rich substrate. As an example, the results of [12] showed that co-digestion of blue algae with swine manure produced $212.7 \mathrm{~mL} \mathrm{CH}_{4} / \mathrm{g}$ VS versus $73.5 \mathrm{~mL} \mathrm{CH}_{4} / \mathrm{g}$ VS when blue algae was digested with sludge. [8] showed in his experiments that the co-digestion of raw algae with animal manure increased the methane yield from 163 to $245 \mathrm{~mL} \mathrm{CH} / \mathrm{g}$ VS. In addition, Algae is characterized by lipids content and [16] mentioned that a source of lipids can expand the biogas yield by $30 \%$.

One particular opportunity, which is the aim of the current paper, is the biogas production from algal biomass and the cattle manure stabilization by codigestion. The co-digestion of cattle manure and raw algae was investigated in the current work at different substrate ratios. The kinetics of methane production were evaluated according to Gompertz model. The substrate ratios were optimized by the Response Surface Methodology (RSM) to enhance the methane potential. Moreover, the effect of adding activated sludge as carbon source and tap water as diluent was explored.

\section{Materials and Methods}

\section{Feedstock and Inoculum}

The algal biomass (A) used in the current study is a growing green algal bloom (Chlorophyta) collected fresh from a dam located in Wadi Kafrein (Jordan) during early to mid-summer. The collected algae samples were kept at $4^{\circ} \mathrm{C}$ in water from the same pond for further use. Cattle manure (CM), which was mainly fresh cattle stool with urine and some straw collected from a commercial semi-intensive farm (Abu Al-Nadi farm located in Zarqa-Jordan). The manure was transferred fresh and directly stored at $4^{\circ} \mathrm{C}$. The activated sludge was used as a carbon source substrate and it was obtained from a secondary thickener in a local wastewater treatment plant at the German Jordanian University in Jordan. The properties of algae, cattle manure, and activated sludge are summarized in Table 1. The mixture of cattle manure and algae was predigested for around 20 day and the the digestate was collected from the anaerobic reactor and it was employed as inoculum during the anaerobic co-digestion.

Table 1. Characteristics of feedstock for batch anaerobic digestion.

\begin{tabular}{|c|c|c|c|}
\hline Parameter & Cattle manure & Algae & Activated sludge \\
\hline Total solids, TS $(\mathrm{g} / \mathrm{kg})$ & $347.5 \pm 3.6$ & $65.7 \pm 2.4$ & - \\
\hline Volatile Solids, $\mathrm{VS}(\mathrm{g} / \mathrm{kg})$ & $19.1 \pm 0.4$ & $2.3 \pm 0.8$ & $1200.72 \pm 15.32$ \\
\hline $\mathrm{COD},(\mathrm{mg} \mathrm{O} / \mathrm{kg})$ & $19300 \pm 0.5$ & $16600 \pm 0.5$ & $75.77 \pm 1.46$ \\
\hline $\mathrm{TN}(\mathrm{mg} / \mathrm{L})$ & 551 & 976 & 16 \\
\hline $\mathrm{COD} / \mathrm{N}$ ratio & 35 & 5.75 & - \\
\hline $\mathrm{TP},(\mathrm{mg} / \mathrm{L})$ & 15 & - & 7.2 \\
\hline $\mathrm{pH}$ & - & & \\
\hline
\end{tabular}




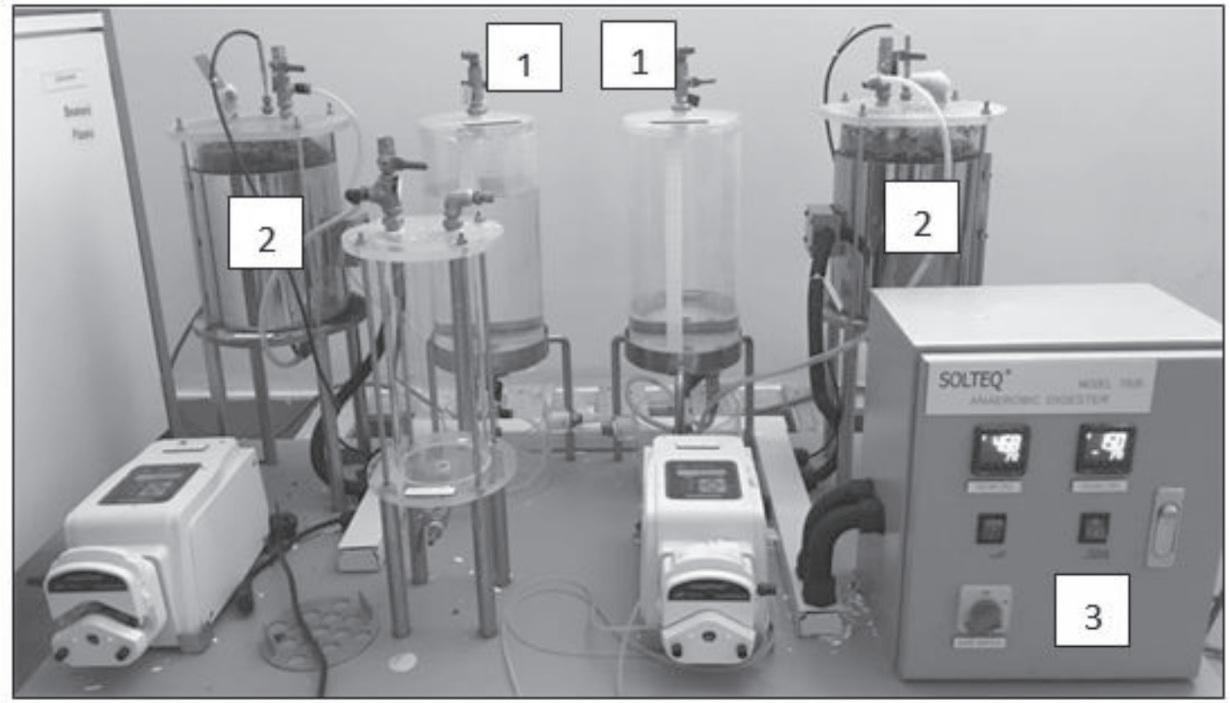

Fig. 1. Experimental setup of anaerobic co-digestion batch tests (1) Gas collection vessel (2) AD reactor (3) Control system.

\section{Batch Anaerobic Digestion Experiments}

Batch AD mesophilic runs were carried out in a 5 L glass reactor (Solteq, Model. TR26) equipped with a $200 \mathrm{~W}$ heating jacket with PID control and a temperature sensor positioned inside each reactor (Fig. 1). The feedstock was not mixed throughout the experiment. All AD assays were performed at $37^{\circ} \mathrm{C}$ and with a working volume of $4 \mathrm{~L}$. The biogas produced during the $\mathrm{AD}$ experiments was collected in a (0-5) L gas vessel filled with water. The gas volume accumulated in the headspace vessel was measured by the acidified water displacement method and it was recorded on a daily basis until almost no further gas was produced (7 to 20 days). The gas volume was adjusted to standard temperature and pressure conditions (STP, $0^{\circ} \mathrm{C}$ and $\left.1 \mathrm{~atm}\right)$. The methane content in the different batch tests was determined by collecting the headspace biogas into plastic bags with a volume of $500 \mathrm{~mL}$ and then measured by a Gas Analyzer (Geotech BIOGAS 5000).

The cattle manure was co- digested with algae at three different substrate ratios based on the (w/w VS) presented in Table 2. The three different mixing ratios were prepared in this first batch in a way to keep the $\mathrm{C} / \mathrm{N}$ ratio in the recommended optimal range. The CM/A mixing ratios studied were as follows: (70\% CM:30\% A, 50\% CM:50\% A, 30\% CM:70\% A) and determined based on the study of [7].
The second two batches of AD assays were conducted in order to optimize methane production. In the first one, activated sludge (AS) was selected to be co-digested with raw algae and cattle manure. The mixtures were prepared at the following (CM: A: AS) mixing ratios (52.5\% CM: $22.5 \%$ A: $25 \%$ AS), $(37.5 \%$ CM: $37.5 \%$ A: $25 \%$ AS), and (22.5\% CM: $52.5 \%$ A: $25 \%$ AS) keeping the CM:A ratios constant at the values mentioned in Table 2. Reference experiments were also prepared with the same mixing ratios however using tap water instead to keep the same working volume of $4 \mathrm{~L}$ and an optimal initial $\mathrm{C} / \mathrm{N}$ ratio. Unlike the batch supplemented with AS, the tap water would provide a dilution effect without altering the COD content of the mixture. The AD experiments carried out in this part are summarized in Table 3.

\section{Analytical Methods}

The substrates were characterized by measuring total solids (TS), (VS), (TN), and (TP) according to APHA Standard Methods 1998 [17]. COD was measured according to Standard Methods 1998 using Hach test kit mid and high range $(0-1500 \mathrm{mg} / \mathrm{L})$ and $(0-15000 \mathrm{mg} / \mathrm{L})$ respectively. The samples were first digested by a Hach digester (DRB 200-Germany) then the COD was measured using a Hach spectrophotometer (DR/2010-Germany).

Table 2. Batch digestion tests at different CM:A mixing ratios with no dilution liquid

\begin{tabular}{|c|c|c|c|c|}
\hline Run & CM:A ratio (based on VS) & Working volume (L) & C/N ratio & Dilution liquid \\
\hline 1 & $70 \%: 30 \%$ & 4 & 27 & No \\
\hline 2 & $50 \%: 50 \%$ & 4 & 23 & No \\
\hline 3 & $30 \%: 70 \%$ & 4 & 20 & No \\
\hline
\end{tabular}


Table 3. Batch digestion tests at different (CM: A: AS) mixing ratios with and without added carbon source keeping the working volume constant.

\begin{tabular}{|c|c|c|c|c|c|c|}
\hline & \multicolumn{6}{|c|}{ Activated Sludge AS } \\
\hline Run & (CM: A: AS) based on VS ratio & CM:A & $\mathrm{C} / \mathrm{N}$ & Working substrates volume (L) & AS volume added (L) & $\mathrm{TS} \%$ \\
\hline 4 & $52.5 \%: 22.5 \%: 25 \%$ & $70 \%: 30 \%$ & 26.8 & 3 & 1 & 7 \\
\hline 5 & $37.5 \%: 37.5 \%: 25 \%$ & $50 \%: 50 \%$ & 23.6 & 3 & 1 & 5 \\
\hline \multirow[t]{2}{*}{6} & $22.5 \%: 52.5 \%: 25 \%$ & $30 \%: 70 \%$ & 20.4 & 3 & 1 & 4 \\
\hline & \multicolumn{6}{|c|}{ Tap Water TW } \\
\hline Run & (CM: A: TW) & CM:A & $\mathrm{C} / \mathrm{N}$ & Working volume (L) & $\begin{array}{l}\text { Tap water volume added } \\
\text { (L) }\end{array}$ & $\mathrm{TS} \%$ \\
\hline 7 & $52.5 \%: 22.5 \%: 25 \%$ & $70 \%: 30 \%$ & 29 & 3 & 1 & 5 \\
\hline 8 & $37.5 \%: 37.5 \%: 25 \%$ & $50 \%: 50 \%$ & 25 & 3 & 1 & 4 \\
\hline 9 & $22.5 \%: 52.5 \%: 25 \%$ & $30 \%: 70 \%$ & 22 & 3 & 1 & 3 \\
\hline
\end{tabular}

\section{The Kinetics of Methane Production}

The kinetics of methane production were analyzed and simulated in the different batch experiments (showing methane production) using the modified Gompertz equation [18].

$$
\mathrm{y}=\mathrm{A} \exp \left\{-\exp \left[\frac{\mu_{m} e}{A}(\lambda-t)+1\right]\right\}
$$

...where $y$ is the volume of methane accumulated in $(\mathrm{mL} / \mathrm{g} \mathrm{VS})$ after time $\mathrm{t}$ (day), $\mathrm{t}$ is the elapsed time (day) over the digestion period. A is the maximum volume of methane produced in $(\mathrm{mL} / \mathrm{g}$ VS) after infinite digestion time. $\mu \mathrm{m}$ is the maximal biogas production rate $(\mathrm{mL} / \mathrm{g}$ VS.d) while $\lambda$ is the lag phase (day). A nonlinear leastsquare (NLLS) regression procedure was followed in order to adjust the model parameters (A and $\mu \mathrm{m}$ ) to the experimental data for each batch test using Excel solver.
The parameters were used to compare the kinetics of the different co-digestion assays and to determine the influence of the substrate ratios on the biogas production.

\section{Application of Design of Experiment (DOE) with RSM}

Design-Expert statistical software (Version 12) for regression was used to apply Response Surface Methodology (RSM) for the optimization of (CM: A: AS) mixing ratio in order to maximize the methane production. Along with the RSM, DOE was also applied to model and analyze the relationship between the response (methane production yield) and the design factors, which were $\mathrm{CM} \%, \mathrm{~A} \%$, and $\mathrm{AS} \%$. The actual experimental design is summarized in Table 4. All process factors in the design has two levels, a maximum and minimum coded as +1 and -1 respectively.

Table 4. DOE matrix for three factors with actual biogas production.

\begin{tabular}{|c|c|c|c|c|}
\hline & Factor A & Factor B & Factor C & Response 1 \\
\hline Run & CM\% & A $\%$ & AS\% & Cumulative methane $(\mathrm{mL} / \mathrm{g} \mathrm{VS})$ \\
\hline 1 & 70 & 30 & 0 & 293.6 \\
\hline 2 & 50 & 50 & 0 & 0 \\
\hline 3 & 30 & 70 & 0 & 4.1 \\
\hline 4 & 52.5 & 22.5 & 25 & 2.9 \\
\hline 5 & 37.5 & 37.5 & 25 & 0 \\
\hline 6 & 22.5 & 52.5 & 25 & 97.1 \\
\hline 7 & 52.5 & 22.5 & 0 (tap water) & 20.9 \\
\hline 8 & 37.5 & 37.5 & 0 (tap water) & 9.3 \\
\hline 9 & 22.5 & 52.5 & (tap water) & \\
\hline
\end{tabular}




\section{Results and Discussion}

\section{Effect of Cattle Manure (CM) to Algae (A) Mixing Ratio on Methane Production with no Dilution of the Feedstock}

This part investigates the effect of mixing ratios of cattle manure and algae on methane production. Prior to effect analysis, it is worth to mention that the COD values measured for raw cattle manure and algae are largely similar to the reported values by [7].

Fig. 2a) displays the cumulative methane yield produced during the batch co-digestion of cattle manure and algae at different mixing ratios. It can be seen that methane production reached stable levels after 15 days. In addition, one key observation is that the introduction of algae in the feedstock with increasing percentage led to a decrease in the cumulative methane yield. The cumulative methane yield dropped from (294 mL/g VS) to $(0 \mathrm{~mL} / \mathrm{g} \mathrm{VS})$ when the $\mathrm{A} \%$ increased from $30 \%$ to $70 \%$. This maximum methane yield exceeds marginally the reported value $(210 \mathrm{~mL} / \mathrm{g}$ VS $)$ by [12]. Moreover, the anaerobic degradation of cattle manure resulted in producing $390 \mathrm{~mL}$ of methane $/ \mathrm{g}$ VS. The inhibition that occurred when adding algae
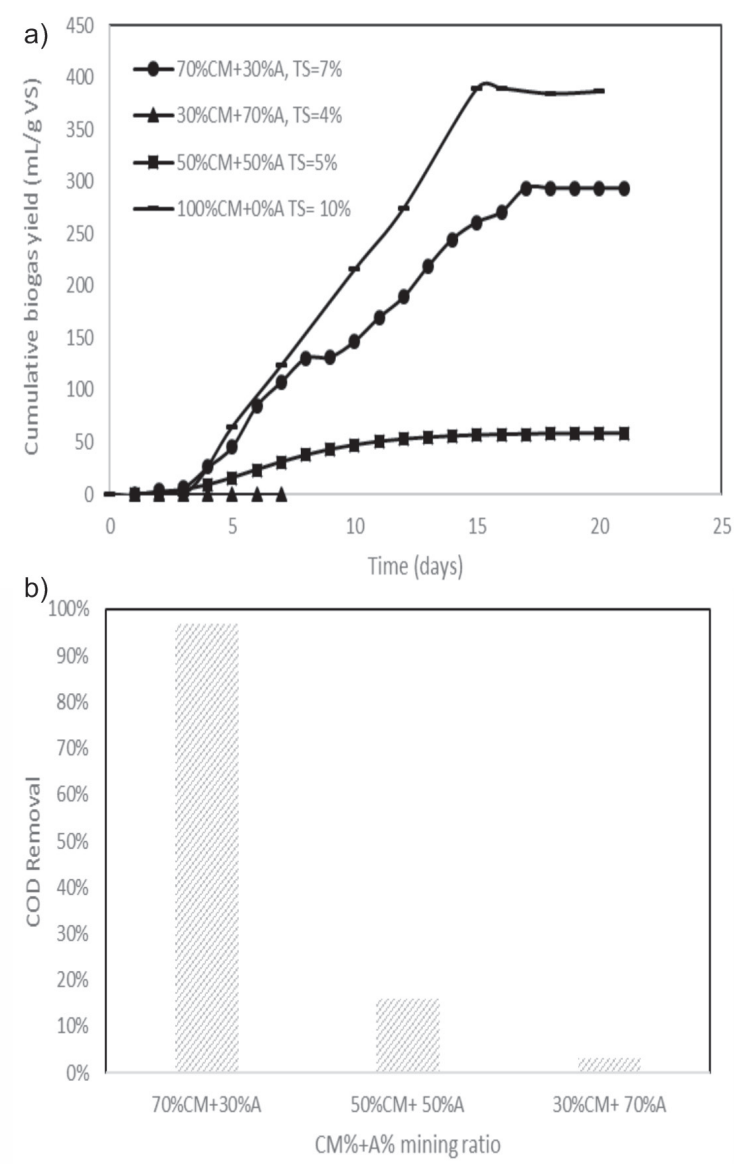

Fig. 2. Cumulative methane yield a) and COD removal b) for anaerobic digestion of cattle manure and algae at different mixing ratios. was also observed in the removal of COD (Fig. 2b) which was $97 \%$ for $30 \%$ of algae in the substrate and dropped to $3 \%$ for $70 \%$ of algae. This can be attributed to the structure of algal wall, which is hardly degraded under anaerobic conditions. The previous results are in agreement with the findings of [7] and [8] who reported that the cellulose or hemicellulose structure of the algal cell wall, which is difficult to degrade under anaerobic conditions, mostly likely inhibited biogas production. The decrease on methane production is related with the low concentration of biodegradable substrates. If algae were added at high percentages this would result in diluting the possible biodegradable substrates on the mixture.

\section{Effect of Cattle Manure (CM) to Algae (A) Mixing Ratio on Methane Production Using Activated Sludge (AS) as Co-Substrate}

The cumulative methane produced from the codigestion of cattle manure, algae and activated sludge under different $\mathrm{CM} / \mathrm{A}$ mixing ratios (runs 4, 5, and 6) as a function of time is shown in Fig. 3a). The cumulative methane yield showed a similar trend at different $\mathrm{CM} / \mathrm{A}$ mixing ratios as the co-digestion cattle manure
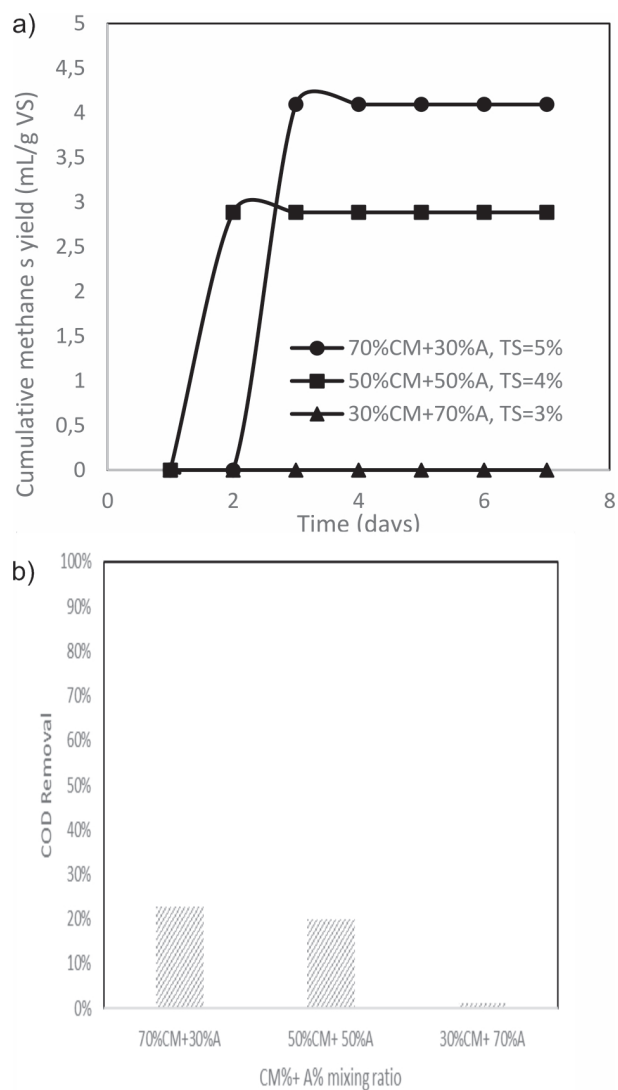

Fig. 3. Cumulative methane yield a) and COD removal b) for anaerobic digestion of cattle manure and algae at different mixing ratios with activated sludge as co-substrate $(25 \%$ based on VS ratio). 

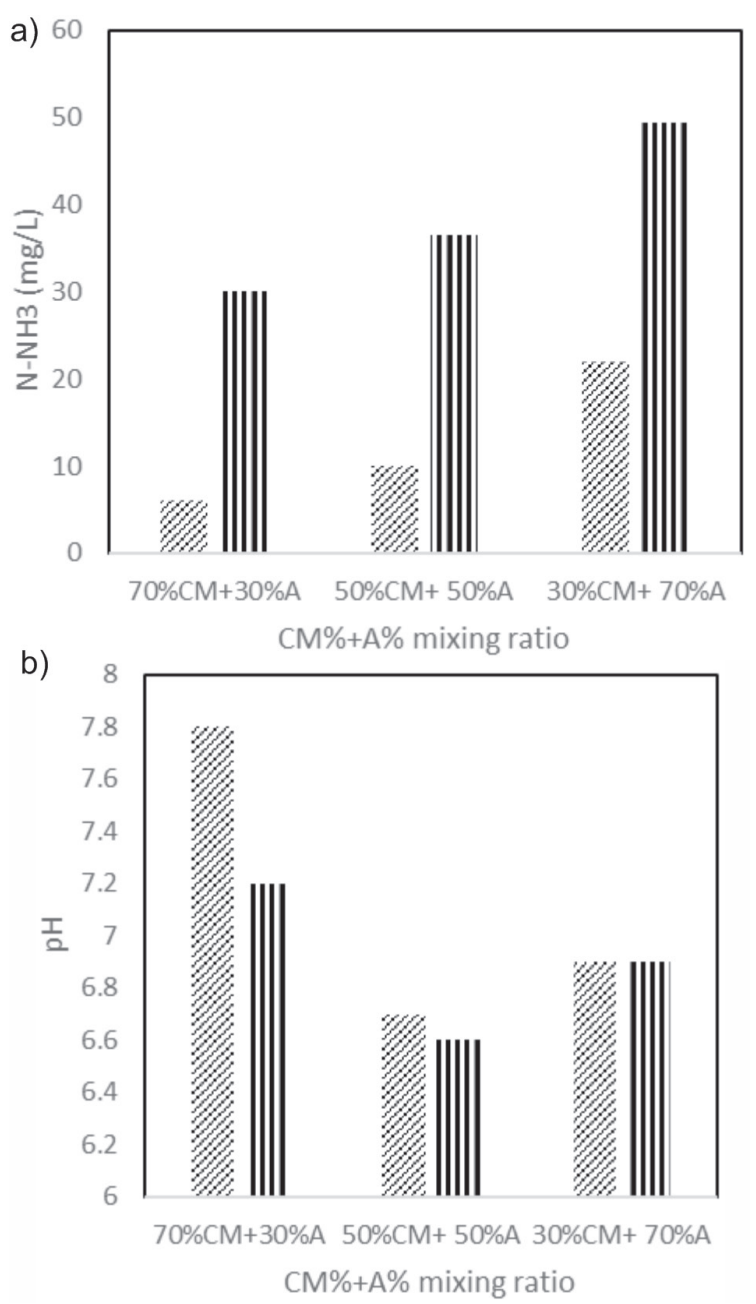

Fig. 4. N-NH $\mathrm{N}_{3}$ a) $\mathrm{pH}$ b) changes at the beginning and at the end of anaerobic digestion of cattle manure and algae at different mixing ratios with activated sludge as co-substrate $(25 \%$ based on VS ratio).

and algae with no added carbon source. It can be seen that increasing the Algae percentage from 30\% to $70 \%$ decreased the biogas yield from $(4 \mathrm{~mL} / \mathrm{g} \mathrm{VS})$ to $(0 \mathrm{~mL} / \mathrm{g} \mathrm{VS})$ respectively. However, digestion of cattle manure/algae supplemented with activated sludge showed dramatically less effective methane cumulative yield. The methane production was almost inhibited. These observations consisted with the experimental results reported by [12] where higher cumulative $\mathrm{CH}_{4}$ yield was obtained when algae was co-digested with manure than with granular sludge. In addition, [19] reported similar results where co-digestion of cattle manure and sewage sludge resulted in minimal methane yield not exceeding $8.75 \mathrm{~mL} / \mathrm{g}$ VS. A reasonable justification could the dilution of the inoculum by adding AS (mainly aerobic or facultative microorganisms). Further investigation shown in Fig. 3b) declared that co digestion of algae and manure with sludge (runs 4, 5, and 6) had dramatically lower COD removal percentage than co digestion of algae and manure with no addition of AS. (runs 1, 2, and 3). The COD removal obtained at

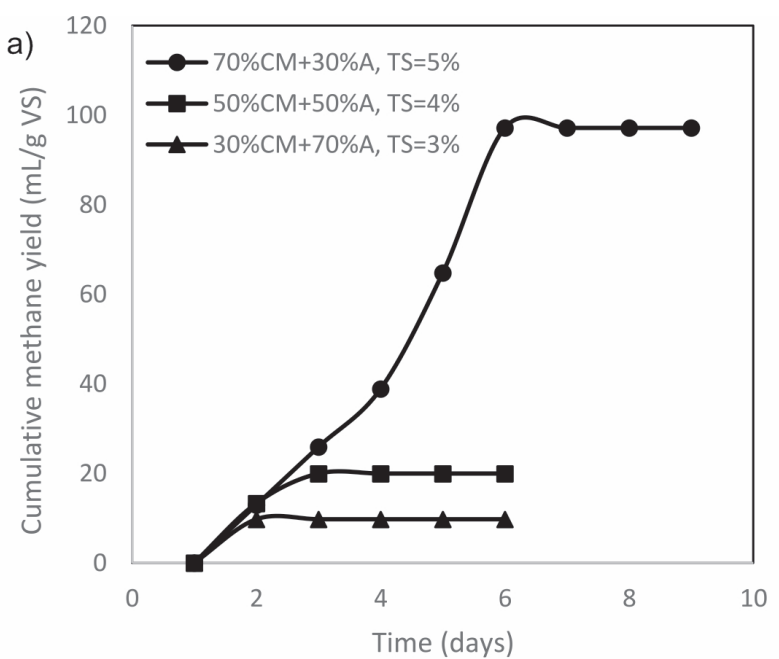

b)

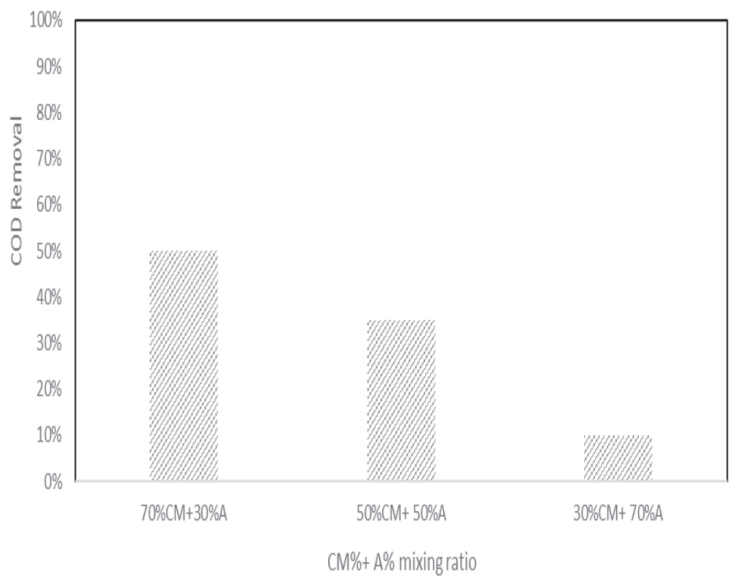

Fig. 5. Cumulative methane yield a) and COD reduction b) for anaerobic digestion of cattle manure and algae at different mixing ratios and diluted with tap water.

mixing ratio $70 \% \mathrm{CM}: 30 \% \mathrm{~A}$ was $23 \%$ and $1 \%$ for $30 \%$ $\mathrm{CM}: 70 \%$ A. One probable reason for the later finding is that the synergy in degradation of cattle manure and raw algae is more noticeable at low Algae content.

To understand the adverse impact of activated sludge, the $\mathrm{pH}$, and $\mathrm{N}_{-} \mathrm{NH}_{3}$ as potential inhibiting factors were measured at the beginning and at the end of the digestion experiment with $\mathrm{AS}$ as co substrate as illustrated in Fig. 4a). The final values of $\mathrm{N}^{-\mathrm{NH}_{3}}$ of the $\mathrm{AD}$ trials at different $\mathrm{CM} / \mathrm{A}$ mixing ratios were $30,36.5$, and $49.5 \mathrm{mg} / \mathrm{L}$ for $70 \% \mathrm{CM}: 30 \% \mathrm{~A}, 50 \%$ CM:50\% A, and 30\% CM:70\% A respectively. All the later $\mathrm{N}-\mathrm{NH}_{3}$ values are below the methanogenic toxicity interval of $80-100 \mathrm{mg} / \mathrm{L}$ [20-21]. This can be justified by the inferior hydrolysis and methanogenesis efficiency of the microorganisms from cattle manure when mixed with sludge. In Fig. 4b) the $\mathrm{pH}$ was fluctuating from 6.6 to 7.8 during the co-digestion of cattle manure and algae with activated sludge as co-substrate. The $\mathrm{pH}$ values at all mixing ratios were maintained at the optimal $\mathrm{pH}$ range. In other words, the $\mathrm{pH}$ was not an inhibition factor for methane production in the case of using sludge as co-substrate. 
Table 5. Summaries of estimated parameters from the Gompertz modified equation for the co-digestion of cattle manure and algae with and without adding activated sludge.

\begin{tabular}{|c|c|c|c|c|}
\hline & Mixing ratio & \multicolumn{3}{|c|}{ Model parameters } \\
\hline Run number as in DOE matrix & CM\%:A\%:AS & $\begin{array}{c}\text { A } \\
(\mathrm{mL} \text { methane/g VS) }\end{array}$ & $\begin{array}{c}\mu_{\mathrm{m}} \\
(\mathrm{mL} / \mathrm{g} \text { VS.d) }\end{array}$ & $\begin{array}{c}\lambda \\
(\mathrm{days})\end{array}$ \\
\hline 1 & $70: 30: 0$ & 332 & 24 & 3.2 \\
\hline 7 & $52.5: 22.5: 0$ & 106.1 & 24.6 & 2 \\
\hline 2 & $50: 50: 0$ & 58.5 & 3.8 & 0 \\
\hline 8 & $37.5: 37.5: 0$ & 20 & 20.7 & 1.2 \\
\hline 9 & $22.5: 52.5: 0$ & 10 & 20.6 & 2.2 \\
\hline 4 & $52.5: 22.5: 25$ & 4.1 & 20.6 & 2.3 \\
\hline 5 & $37.5: 37.5: 25$ & 2.9 & \\
\hline
\end{tabular}

Effect of Cattle Manure (CM) to Algae (A) Mixing Ratio on Methane Production Using Tap Water (TW) as Diluent

Several batch assays in this part were prepared with the same CM: A mixing ratios 70\% CM:30\% A, 50\% CM:50\% A, and 30\% CM:70\% A and diluted with tap water (runs 7, 8, and 9). Fig. 5a) shows the cumulative biogas yield under different ratios of $\mathrm{CM}$ to Algae diluted with tap water to probably stimulate methane production. It can be seen that the biogas yield showed the same trend as in the co-digestion of $\mathrm{CM}$ and $\mathrm{A}$ with no dilution, where it increased with increasing the $\mathrm{CM} \%$ in the mixture. However, the dilution had no positive effect on the biogas yield. The maximum methane yield achieved was $97 \mathrm{~mL} / \mathrm{g}$ VS with $70 \% \mathrm{CM}: 30 \% \mathrm{~A}$ and TS of 5\% with dilution where it was $294 \mathrm{~mL} / \mathrm{g}$ VS with no dilution (Fig. 2a). It is also noticed that the methane yield has increased with increasing the TS\%. However, the lower TS content of those assays also implies a dilution of the biodegradable substrates. These results also suggest that no inhibitory levels were reached with the TS percentages and $\mathrm{CM} / \mathrm{A}$ ratios tested [22] in this part. The COD removal results (Fig. 5 b) are in accordance with the biogas yield where the maximum removal was $50 \%$ obtained at $70 \% \mathrm{CM}: 30 \% \mathrm{~A}$ and a TS of $5 \%$.

\section{The Kinetics of Methane Production}

In order to investigate the methane production thoroughly, the experimental data collected from the cumulative methane production were fitted to the modified Gompertz model. The regression results (A, $\mu_{\mathrm{m}}$, and $\lambda$ ) are summarized in Table 5 . The A values predicted from the Gompertz modified model are slightly higher than the experimental values. However, the results confirm the later observations in which the methane yield increases with increasing the $\mathrm{CM} \%$ in the feedstock. The maximum methane yield $(332 \mathrm{~mL} / \mathrm{g}$ VS) was obtained for $\mathrm{CM} \%: \mathrm{A} \%: \mathrm{AS} \%$ mixing ratio of 70:30:0. Similarly, The $\mu_{m}$ values were lower when AS was added to the same mixing ratios. For example, $\mu_{m}$ went down from $32.4 \mathrm{~mL} / \mathrm{g}$ VS. in run 8 to $20.6 \mathrm{~mL} / \mathrm{g}$ VS.d. in run 5. In other words an $\mathrm{CM} \%: \mathrm{A} \%: \mathrm{AS} \%$ mixing ratio of 37.5:37.5:0 was the most efficient to accelerate the biogas production rate. Interestingly, the experiment with the highest methane exhibited the longest lag phase time. The $\lambda$ ranged from 0 to 3.2 days with the longest lag phase time $(3.2 \mathrm{~d})$ at $70: 30: 0$ and the shortest $(0 \mathrm{~d})$ at 37.5:37.5:0. Usually this lag phase is related with the initial hydrolytic phase of anaerobic digestion. As it can be noticed from Table 5, the longest lag phases are 3.2 and 3 days for the runs 1 and 2, which are characterized by undiluted and high percentage of cattle manure mixtures.

\section{Optimization of Methane Production from Co-Digestion of Cattle Manure and Algae with and Without Activated Sludge: Effect of CM\%:A\% Ratio}

This section is to investigate the effect of CM\%:A\%:AS\% on the ultimate methane yield as well. Based on the 9 runs of the DOE (Table 4), the following coded polynomial equation is obtained.

Methane yield $(\mathrm{mL} / \mathrm{g} \mathrm{VS})=37.5+428.89 \times(\mathrm{CM} \%)+$ $61.69 \times(\mathrm{A} \%)\left(+172.07(\mathrm{CM} \%) \times(\mathrm{A} \%)+580.83(\mathrm{CM} \%)^{2}\right.$

Table 6. Statistics used to test the adequacy of the reduced models.

\begin{tabular}{|c|c|c|c|c|}
\hline Response & F-value & $\mathrm{R}^{2}$ & p-value & Adequate precision (Ratio $>4)$ \\
\hline Methane Yield (mL/g VS) & 12.34 & 0.9250 & 0.016 & 10.63 \\
\hline
\end{tabular}




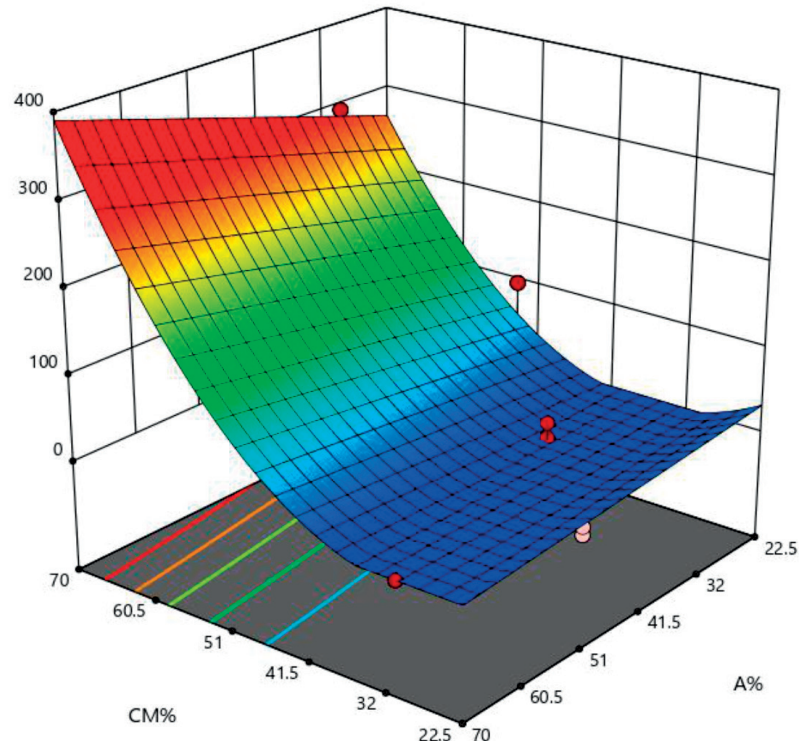

Fig. 6. Response surface plot for methane yield vs $\mathrm{CM} \%$ and $\mathrm{A} \%$ at $0 \% \mathrm{AS}$.

The results of the statistical analysis for the methane yield response are shown in Table 6. The quadratic regression shows that the model was significant as evident from the F-value, p-value and the correlation coefficient $\mathrm{R}^{2}$ checked by ANOVA at the 95\% confidence level. In addition, "Adeq Precision" should exceed a ratio of 4 for the model to be statistically significant. The "Adeq Precision" value for the reduced model is 10.63 .

The 3D surface plot (Fig. 6) demonstrates the optimal design factors $(\mathrm{CM} \%$ and $\mathrm{A} \%)$ that can be calculated by solving the polynomial equation. Fig. 6 depicts the effect of $\mathrm{CM} \%$ and the $\mathrm{A} \%$ on the ultimate methane yield. It can be concluded from the figure that the optimum methane yield is not within the designated boundaries. However, the maximum methane yield within the investigated range $(399 \mathrm{~mL} / \mathrm{g}$ VS) was observed at $70 \%$ CM:30\%A:0\%AS. The optimum value of $\mathrm{CM} \%$ supports the fact that low methane yields were recorded at high $\mathrm{A} \%$ due to the structure of algal wall, which is hardly degraded under anaerobic conditions.

\section{Conclusion}

Co-digestion of cattle manure and raw algae without dilution or AS addition resulted in an ultimate methane yield of $294 \mathrm{~mL} / \mathrm{g} \mathrm{VS}$. However, mixing the feedstock with activated sludge dropped the methane production markedly to $4 \mathrm{~mL} / \mathrm{g}$ VS at the optimal CM:A ratio. The results of $\mathrm{pH}$ and free ammonia demonstrated no inhibitory effects. Finally, the dilution of the feedstock using tap water lowered the optimal methane yield from $294 \mathrm{~mL} / \mathrm{g}$ VS (70\% CM:30\%A) to $97 \mathrm{~mL} / \mathrm{g} \mathrm{VS}$.

\section{Conflict of Interest}

The authors declare no conflict of interest.

\section{References}

1. DI MARIA F., SORDI A., MICALE C. Energy production from mechanical biological treatment and composting plants exploiting solid anaerobic digestion batch: an Italian case study. Energy Convers. Manage. 56, 112, 2012.

2. WARD A.J., LEWIS D.M., GREEN F.B. Anaerobic digestion of algae biomass: A review. Algal Research 5, 204, 2014.

3. ABDELHAY A., ALBSOUL A., HADIDI F., ABUOTHMAN A. A Optimization and Modeling of Biogas Production From Green Waste/Biowaste CoDigestion Using Leachate and Sludge. Clean - Soil, Air, Water. 44 (9999), 1, 2016.

4. LI R., DUAN N., ZHANG Y., LIU Z., LI B., ZHANG D., LU H., DONG T. Co-digestion of chicken manure and microalgae Chlorella 1067 grown in the recycled digestate: Nutrients reuse and biogas enhancement. Waste Manage. 70, 247, 2017.

5. BROWN D., LI Y. Solid state anaerobic co-digestion of yard waste and food waste for biogas production. Bioresour. Technol. 127, 275, 2013.

6. ZHANG T., YANG Y., LIU L., HAN, Y., REN, G., YANG, G. Improved biogas production from chicken manure anaerobic digestion using cereal residues as co-substrates. Energy Fuel 28, $2490,2014$.

7. WANG M., LEE E., ZHANG Q., ERGAS S.J. Anaerobic co-digestion of swine manure and microalgae Chlorella sp.: experimental studies and energy analysis. Bioenerg. Res. 9, 1204, 2016.

8. ASTALS S., MUSENZE R.S., BAI X., TANNOCK S., TAIT S., PRATT S., JENSEN P.D. Anaerobic co-digestion of pig manure and algae: impact of intracellular algal products recovery on co-digestion performance. Bioresour. Technol. 181, 97, 2015.

9. BERNET N., BÉLINE F. Challenges and innovations on biological treatment of livestock effluents. Bioresour. Technol. 100 (22), 5431, 2009.

10. TUFANER F., AVSAR Y. Effects of co-substrate on biogas production from cattle manure:a review. Int. J. Environ. Sci. Technol. 13, 2303, 2016.

11. MATA-ALVAREZ J., DOSTA J., MACÉ S., ASTALS S. Codigestion of solid wastes: a review of its uses and perspectives including modeling. Crit. Rev. Biotechnol. 31 (2), 99, 2011.

12. MIAO H., WANG S., ZHAO M., HUANG Z., REN H., YAN Q., RUAN W. Codigestion of Taihu blue algae with swine manure for biogas production. Energy Convers.Manage. 77, 643, 2014.

13. SARKER S., MØLLER HB., BRUHN A. Influence of variable feeding on mesophilic and thermophilic co-digestion of Laminaria digitate and cattle manure. Energy Convers.Manage. 87, 513, 2014. 
14. RAMOS-SUÁREZ J.L., CARRERAS N. Use of microalgae residues for biogas production. Chem. Eng. J. 242, 86, 2014.

15. MATA-ALVAREZ J., DOSTA J., ROMERO-GÜIZA MS., FONOLL X., PECES M., ASTALS S. A critical review on anaerobic co-digestion achievements between 2010 and 2013. Renew. Sustain. Energy Rev. 36, 412, 2014.

16. HUNTER LONG J., AZIZ TN., REYES FL., DUCOSTE J.J. Anaerobic co-digestion of fat, oil, and grease (FOG): A review of gas production and process limitations. Process Saf. Environ. 90, 231, 2012.

17. APHA, Standard Methods for the Examination of Water and Wastewater, 20 ${ }^{\text {th }}$ Ed., American Public Health Association, Washington DC, USA 1998.

18. BENBELKACEM H., BAYARD R., ABDELHAY A., ZHANG Y., GOURDON R. Effect of leachate injection modes on municipal solid waste degradation in anaerobic bioreactor. Bioresour. Technol. 101, 5206, 2010.
19. GARCÍA, K., PÉREZ M. Anaerobic Co-digestion of Cattle Manure and Sewage Sludge: Influence of Composition and Temperature. Int. J. Environ Protection. 3 (6), 8, 2013.

20. NIELSEN H.B., ANGELIDAKI I. Strategies for optimizing recovery of the biogas process following ammonia inhibition. Bioresour. Technol. 99, 7995, 2008.

21. SNELL-CASTRO R., GODON J.J., DELGENES J.P., DABERT P. Characterization of the microbial diversity in a pig manure storage pit using small subunit rDNA sequence analysis". FEMS Microbiol. Ecol. 52, 229, 2005.

22. COSTA J.C., GONÇALVES P.R., NOBRE A., ALVES M.M. Biomethanation potential of macroalgae Ulva spp. and Gracilaria spp. and in co-digestion with waste activated sludge. Bioresour. Technol. 114, 320, 2012. 
